\title{
Restorative therapy in stroke using stem cells
}

\author{
M. V. Padma Srivastava \\ Department of Neurology, All India Institute of Medical Sciences, New Delhi - 110 029, India
}

\author{
Address for correspondence: \\ Dr. M. V. Padma Srivastava, \\ Room No. 708, CN Center, \\ Department of Neurology, AlIMS, \\ New Delhi - 110029, India. \\ E-mail: vasanthapadma123@ \\ rediffmail.com
}

\begin{abstract}
The nonregenerative capability of the injured adult brain has been challenged in recent years and neural plasticity has been observed experimentally in both global and focal brain ischemia in animal models. Whether neuro-genesis increases in response to brain lesions or stem cells can be used for transplantation are the potential Questions to be answered. Functional recovery may occur in a small or a localized brain injury using rehabilitation measures, but for large ischemic strokes, the restoration may require new synaptic connections within and away from the damaged tissue. In an infarcted area, the ischemic core may not respond to any pharmacological or rehabilitative intervention. For these reasons, the prospects of repairing the neuron system, using cell transplantation seems promising and may offer a unique approach for brain repair and restoration of function. On going animal and human trials have greatly helped us to burgeon our hopes on this method of restorative therapy after stroke. The ultimate aim of any therapeutic strategy is the maximum restoration possible and eventual complete normalcy of function.
\end{abstract}

Key words: Brain plasticity, neuroregeneration, restorative therapies, stem cells, stroke

\section{Introduction}

The hope to create a healthier world without discarding fundamental values of professionalism and ethics, and the fear of worsening the scenario by following a hype based on pseudoscience, opportunism, and unethical practices, is what plagues the true scientist and healer. There is no better way to aptly describe the hope and hype regarding stem cell therapy. The ultimate aim of any therapeutic strategy is the maximum restoration possible and eventual complete normalcy of function. The nonregenerative capability of the injured adult brain has been challenged in recent years and neural plasticity has been observed experimentally in both global and focal brain ischemia in animal models. ${ }^{[1]}$ Functional recovery may occur in a small brain injury using rehabilitation measures, but for large ischemic strokes, the restoration may require new synaptic connections within and away from the damaged tissue. In an infarcted area, the ischemic core may not respond to any pharmacological or rehabilitative intervention. For these reasons, the prospects of repairing the neuron system, using cell transplantation seem promising and may offer a unique approach for brain repair and restoration of function. ${ }^{[2-4]}$
Compared to neurodegenerative disease, stroke poses special conditions that impact the potential success of transplantation to enhance neurological recovery, including the anatomy and the time of stroke, the vascular supply, site of implantation, and type of patients enrolled in the clinical trials. ${ }^{[5]}$ In contrast to a neurodegenerative disorder such as Parkinson's disease (PD), which destroys a relatively homogenous population of neurons, strokes affect multiple different neuronal phenotypes. An infarct might involve the thalamus, hippocampus, and striate visual cortex affecting three or more very different neuronal populations. Besides, oligodendrocytes, astrocytes and endothelial cells are also affected. Reconstitution of the complex and widespread neuronal-glial-endothelial interrelationships may require cells for transplant to initially remain immature and phenotypically plastic to differentiate into appropriate neural, glial, and endothelial cell types depending on the damaged area. If white matter is destroyed in a stroke, cell implants may not produce functional connections with axons that can penetrate through the scar tissue of a chronic infarct. 
There is uncertainty about the mechanism(s) by which cell transplantation might improve stroke deficits. Transplanted cells ideally should replace cells that are damaged by ischemia and take over function of these cellular elements. However, it is also possible that transplanted cells secrete trophic factors that help to maintain marginally surviving cells or otherwise enhance the local environment sufficiently to improve function. Transplantation might also conceivably produce a host reaction that could include sprouting of new axons and synapse formation.

\section{Cell types and Sources of Intracerebral Grafting}

The most important issue in any cell transplantation technique would be the availability of appropriate cell type having the ability to proliferate in vivo, structurally and functionally integrate into the brain. It is important that cellular elements used in transplantation should be immature and phenotypically plastic so as to differentiate into different cell types i.e., neural or glial depending upon the site of implant. Following cell types [Table 1], have been studied as potential candidates for neural repair in ischemic stroke: ${ }^{[6]}$

\section{Embryonic/fetal cells}

Fetal tissue has been the major source of cell transplantation in animal models of stroke. Since there are major ethical and legal issues governing the use of "human fetal embryonic tissue," other cell sources are being seriously considered and investigated. ${ }^{[7-9]}$ Pigs are useful as donors as they are nonendangered species and produce large litters. Transplantation of fetal cells from primordial striatum of porcine origin, known as lateral ganglionic eminence (LGE) was shown to improve function in rat ischemic models. ${ }^{[8]}$ The likelihood of graft rejection in humans is of potential concern and strategies need to be devised to overcome this. ${ }^{[10,11]}$ It has been reported that porcine endogenous retrovirus particles (PERV) could be released from the porcine cell lines and can infect human cell lines. Since then a debate on PERV infection from xenotransplantation or its integration into human retrovirus, with resultant novel mutations has been ongoing ${ }^{[12,13]}$ Guidelines call for regular monitoring of patients undergoing xenotransplantation.

\section{Immortalized cell lines}

These cell lines are derived by infecting neuroepithelial precursor cells from predefined central nervous system (CNS) regions before their terminal mitosis, with a retrovirus encoding an immortalizing oncogene. ${ }^{[14,15]}$ The advantage of establishing an immortalized cell line is in providing an unlimited number of identical cells from a single cell propagated in culture, higher level of neurotransmitter production using genetic
Table 1: Various cell types under investigation for

transplantation in experimental and clinical stroke trials

\begin{tabular}{|c|c|c|c|}
\hline Cell type & Description & Advantages & Disadvantages \\
\hline NT2N & $\begin{array}{l}\text { Immortalized } \\
\text { cell line }\end{array}$ & $\begin{array}{l}\text { Unlimited supply } \\
\text { long-term safety }\end{array}$ & Lineage restricted \\
\hline LGE & Fetal pig & Abundant supply & $\begin{array}{l}\text { Lineage restricted } \\
\text { pig infections }\end{array}$ \\
\hline BMSC & Bone marrow & Autologous & $\begin{array}{l}\text { Painful extraction } \\
\text { IV approach may } \\
\text { affect other organs }\end{array}$ \\
\hline HUCBC & $\begin{array}{l}\text { Umbilical } \\
\text { cord blood } \\
\text { cells }\end{array}$ & Aternate source & Incomplete studies \\
\hline Adipose & $\begin{array}{l}\text { Stromal } \\
\text { stem cells }\end{array}$ & Abundant source & Incomplete studies \\
\hline NSC & $\begin{array}{l}\text { Neural } \\
\text { stem cells }\end{array}$ & $\begin{array}{l}\text { Extraction from } \\
\text { patient }\end{array}$ & Incomplete studies \\
\hline
\end{tabular}

NT2-N-Tera-2 cells; NSC- Neural stem cells; HUBCS-Human umbilical cord blood cells; BMSC- Bone marrow stromal cells; LGE-Lateral ganglionic eminence

manipulation, better pooling and sorting of viable cells, screening for infectious diseases and efficient planning of surgical procedure.

Spontaneously arising neural cell lines or neuron like cells $\mathrm{N}-\mathrm{Tera}-2$ neuron (NT2N) cells were derived from human testicular germ cell tumor, years ago. Also called LBS-neurons (after Layton Bioscience Inc. Ath. Cal), the credit of development and patenting of the process to cleverly transform this rapidly dividing cell line into fully differentiated nondividing neurons goes to researchers at University of Pittsburg, Pennsylvania. NT2N cells, are "Neuron Like Cells" as they have a symmetrical morphology, elaborate an extended axon and elongated dendrite. ${ }^{[16,17]}$ These cells can express neurotransmitters, functional glutamate receptors, calcium channels and proteins capable of secretory activity and synaptogenesis. The ready constant availability of cryopreserved pure neurons, has made the NT2N cells an attractive graft source and trials in animal studies and initial results in ongoing clinical trials in humans are encouraging. ${ }^{[18,19]}$

\section{Stem cells}

The discovery of adult tissue specific stem cells, such as hematopoetic stem cells, having ability to differentiate into other tissues has generated immense interest among cell biologists and transplant clinicians. ${ }^{[20]}$ Stem cells are cells capable of proliferation, self-maintenance, and production of differentiated functional progeny that are characteristic of the organ from which they are derived. In adult animals stem cells are present in organs like bone marrow, skeletal muscle, intestine, liver, peripheral nervous system and retina, etc. ${ }^{[21-23]}$

\section{Bone marrow stromal cells}

The bone marrow stromal cells (BMSCs) under specific conditions differentiates into a variety of tissue, for 
example, bone, cartilage, muscle, glia and neurons. When exposed to epidermal growth factor or neurotrophic factors such as brain derived neurotrophic factor (BDNF) in vitro, or cultured with neural cells, human BMSCs differentiate into cells, expressing neural precursor cells (NPC) markers. ${ }^{[24,25]}$ The advantages with these cell lines seem many. Obtaining marrow cells would be easy and expanding them in culture would not be that difficult. Using patient's own BMSC would theoretically eliminate the risk of rejection. However, differentiation mechanism for these cells is poorly understood. Whether these cells truly produce neuronal synaptic network with plasticity or produce trophic factors alone is questionable and speculative. ${ }^{[26]}$ Issues such as long-term survival, safety, plasticity and behavior of BMSCs need further evaluation before clinical use.

\section{Umbilical cord blood cells}

Human umbilical cord blood may also harbor cells (human umbilical cord blood cells [HUCBs]) capable of differentiation into neural lineages. When exposed to nerve growth factor (NGF) and RA, the derived umbilical cells produce progeny that show positivity of neural and glial cells markers. ${ }^{[27]}$

\section{How do Transplanted Cells Work?}

In most cases of neural transplantation, it is likely that therapeutic effects of the implanted neurons or their precursors, would be dependent upon their functional and structural integration into the brain tissue. ${ }^{[28]}$ The functional benefits after neural transplantation are likely to be mediated by one of the following mechanisms. ${ }^{[28-31]}$

1. Neurotransmitters released from the graft tissue act on the afferent deprived limb of the post synaptic receptors.

2. Release of the neurotrophic/growth factors (BDNF, glial derived neurotrophic factor [GDNF], NGF, etc.) acting as local pumps to support cell function and to prevent cascade of apoptosis. Regenerating neuronal population further prevents subsequent cell death.

3. Reestablishment of local interneuronal connections and synaptic connectivity between the host and graft.

4. Cell differentiation and integration.

5. Improvement of regional oxygen tension.

6. Limit glial reaction and prevent retrograde degeneration.

Possibly, the overall success of functional outcome is mediated by a combination of the above mentioned factors.

\section{Types of Stroke Lesions Amenable to Stem Cell Therapy}

Not all stroke lesions may be amenable to cell transplantation. Most preclinical studies involve intrastriatal implantation. Cortical lesions also may be accessible to transplantation, but infarcts involving white matter are more problematic. A proliferation of transplanted cells in the cortex may not necessarily repair underlying axonal damage. There is even rationale for neural transplantation in patients with pure white matter infarcts, which require, an entirely different therapeutic strategy. The size and extent of infarction involving major arterial territories will play a significant role in patient selection. In patients with widespread damage, the number of cells potentially needed to restore function may be daunting.

\section{Timing of Stem Cell Transplantation After Stroke}

The appropriate time to transplant after a stroke is unknown. In the acute setting, release of excitotoxic neurotransmitters, free radicals, proinflammatory mediators might threaten new tissue introduced into the peri-infarct region. Also, cells may be dying by apoptosis in the penumbra for several weeks after stroke. Inflammation leading to microglial activation may inhibit endogenous neurogenesis and may thereby suppress the growth and survival of transplanted cells. ${ }^{\text {[2]] }}$

On the other hand, in the acute stage, local repair processes are active, including the release of neurotrophic factors from the intrinsic milieu and the host environment during the early phase to facilitate implant growth, survival, differentiation and/or integration. The ischemic environment also promotes the generation of new neurons in periventricular regions and in the cerebral cortex. ${ }^{[28]}$ How transplantation will affect the ongoing endogenous neurogenesis is unknown. There is accumulating evidence that stroke recovery involves plasticity of connections, which occur early after a stroke but may disappear months or years later. Transplantation might benefit from such plasticity and become maximally beneficial during this reorganization.

However, delaying the stem cell transplantation for several weeks after stroke must also contend with the disadvantage of formation of scar tissue which might adversely affect implanted cells. The choice of timing must also consider the natural course of recovery from stroke. Many neurologists would therefore prefer to delay transplantation till the deficit plateaus. The two clinical trials in chronic stroke have chosen to study disabled patients at least six months after a stroke. However, there 
are no corroborating animal models of chronic stroke. Most importantly, recovery in animals, cannot be easily equated across studies or related to humans.

\section{Site of Implant}

From a mechanical point of view, injection of cells into the fluid-filled cavity of a chronic infarct facilitates the migration of transplanted cells. Without a definable cavitated area, transplantation requires more direct pressure to inject risking damage to normal tissue. However, cavity fluid can dilute the concentration of donor cells.

In the acute setting, it may be appropriate to inject cells in the salvageable penumbra but grafts might still be exposed to the detrimental effects of spreading depression and excitatory neurotransmitters. ${ }^{[29]}$ Fetal cortical grafts to the ischemic brain have been shown to survive in the penumbra but not in the core lesion. ${ }^{[2]}$ However, in chronic infarcts, glial scarring might impede the delivery of cells to the penumbral areas.

\section{Animal Studies}

Stem/precursor cells from different sources have been tested for their ability to reconstruct the forebrain and improve function after transplantation in animals subjected to stroke. Many rodent studies have demonstrated that stem cell transplantation by surgery, direct injections to the brain, and less invasive intravenous infusion, can improve stroke recovery. ${ }^{[29-39]}$

But the underlying reasons for the success of these therapies remain largely unknown. The researchers use various strains of rodents and stroke models; they implant, infuse and inject different cell types; they put the cells in different target locations in the brain and employ different behavior tests to assess functional recovery. All these variables, without standard treatment protocols and outcome measures, make it difficult to compare studies and determine the best conditions for stem cell therapy following a stroke [Table 2].

\section{Clinical Trials}

\section{NT2 neuron cell trials}

Phase 1

This clinical trial assessed the safety of intrastriatal NT2N (produced by Layton Bioscience Inc. and known as LBS neurons for human use) transplantation in patients with basal ganglia infarcts and stable motor deficits six months to six years before transplantation. ${ }^{[0]}$ Twelve patients were treated with NT2N cell transplants and immunosuppressed using cyclosporine
Table 2: Properties of stem/precursor cells grafted in animal models of stroke

\begin{tabular}{|c|c|}
\hline $\begin{array}{l}\text { Cell source and } \\
\text { transplantation approach }\end{array}$ & Effect on behavioral deficit \\
\hline $\begin{array}{l}\text { Rat SVZ precursors in rat cisterna } \\
\text { magna }^{[31]}\end{array}$ & $\begin{array}{l}\text { Improved sensorimotor } \\
\text { function }\end{array}$ \\
\hline $\begin{array}{l}\text { Mouse neuroepithelial stem } \\
\text { cell line in rat cortex, striatum or } \\
\text { ventricle }^{[32-34]}\end{array}$ & $\begin{array}{l}\text { Improved sensorimotor } \\
\text { function or spatial memory }\end{array}$ \\
\hline $\begin{array}{l}\text { Human fetal teratomcarcinoma } \\
\text { cell line (NT2) in rat striatum }{ }^{[39]}\end{array}$ & $\begin{array}{l}\text { Improved passive avoidance } \\
\text { task and symmetric motor } \\
\text { behavior }\end{array}$ \\
\hline $\begin{array}{l}\text { Immortalized mouse cerebellar } \\
\text { precursors on polymer scaffold in } \\
\text { mouse cortex }\end{array}$ & $?$ \\
\hline $\begin{array}{l}\text { Rat bone marrow stromal cells } \\
\text { systemically or in penumbra zone } \\
\text { in rat striatum }{ }^{[36]}\end{array}$ & $\begin{array}{l}\text { Improved sensorimotor } \\
\text { function and neurological } \\
\text { severity score }\end{array}$ \\
\hline $\begin{array}{l}\text { Human bone marrow stromal } \\
\text { cells systemically in rats }{ }^{[38]}\end{array}$ & $\begin{array}{l}\text { Improved sensorimotor } \\
\text { function neurological severity } \\
\text { score }\end{array}$ \\
\hline $\begin{array}{l}\text { Human umbilical cord blood } \\
\text { cells systemically in rats }{ }^{[3]]}\end{array}$ & $\begin{array}{l}\text { Improved sensorimotor } \\
\text { function neurological } \\
\text { severity score }\end{array}$ \\
\hline
\end{tabular}

SVZ- Sub ventricular zone; NT2 - N-Tera -2 cells

for nine weeks. Based on preclinical safety data, doses of 2 and 6 million cells were considered appropriate. On autopsy examination of one of these patients, who did not show clinical improvement and died of myocardial infarction, the graft site showed no signs of inflammation, neoplasia or infectious disease 27 months after implantation. Because NT2N cells are polyploidy for chromosome 21, grafted neurons were identified at the injection site with fluorescent in situ hybridization and DNA probes specific to this distinctive chromosomal feature. ${ }^{[40,41]}$ Positron emission tomography (PET) scanning at six months showed greater than $15 \%$ relative uptake of F-18 flourodeoxyglucose at the transplant site in six patients. ${ }^{[42]}$ This may reflect surviving and functioning implanted cells, enhanced host cell activity or an inflammatory response.

\section{Phase 2}

In this randomized open-label trial, 14 patients were randomized to receive 5 or 10 million implanted cells followed by rehabilitation, compared to four patients who only underwent physiotherapy. Patients had stable motor deficits 1-6 years after the onset of stroke. Half the patients had an ischemic stroke, and the other half had a hemorrhage. One patient had a single seizure and another had a subdural hematoma evacuated one month after the transplantation. There were no cellassociated adverse events. Transplant patients showed a trend towards improvement in functional outcomes on several scales compared to baseline measurements before transplantation, but there were no statistically significant trends compared to the four controls. ${ }^{[43]}$ 


\section{Diacrin trial}

\section{Phase 1}

The original goal was to enroll 12 patients with chronic, stable, moderate-sized basal ganglia infarcts who would receive intrastriatal implantation of fetal cells from the porcine, primordial striatum, also called the LGE of porcine embryonic tissue and pretreated in culture with an antimajor histocompatability complex class I antibody, thus obviating the need for immunesuppression after transplantation. Five patients underwent transplantation. Their strokes occurred on an average five years earlier. One patient developed cortical vein occlusion thought to be related to the surgery, but the food and drug administration (FDA) terminated the study. After two years of treatment, one of the patients showed improvement on the modified rankin scale (MRS).

\section{The Korean University trial}

This was a randomized controlled phase I/II trial. ${ }^{[4]}$ Cell transplantation improved recovery from ischemic stroke in 30 patients with intravenous autologous mesenchymal stem cells infusion. They prospectively and randomly allocated 30 patients with cerebral infarcts with middle cerebral artery territory and with severe neurological deficits into two treatment groups: The MSC group $(n=5)$ received intravenous infusion of $1 \times 10^{8}$ autologous MSCs, whereas the control group $(\mathrm{n}=25) \mathrm{did}$ not receive MSCs. MSC treated patients received $5 \times 10^{7}$ cells twice: 4 to 5 (first boosting) and 7 to 9 weeks (second boosting) over 15-20 minutes. Neurological deficits and improvements in function were compared between the groups for an year after symptom onset. Outcomes improved with the MSC treated patients than with the control group.

\section{Adult Stem Cell Therapy in Stroke}

Adult stem cell therapy for stroke can be divided in an endogenous and exogenous approach. The aim of the endogenous stem cell therapy is to exploit the population of adult stem cells already physiologically present either in the CNS or the hematopoetic system derived adult stem or precursor cells are administered locally or systemically after purification and propagation in culture.

Interestingly, acute cerebral ischemia in human individuals leads spontaneously to a threefold increase in CD $34^{+}$cell count in the peripheral blood. Considering this change as an insufficient self-repair mechanism, it is a logical consequence to further promote $\mathrm{CD} 34^{+}$cell mobilization pharmacologically by the administration of granulocyte colony stimulating factor (G-CSF). In addition, G-CSF has been described to exert neuroprotective effects following cerebral ischemia. A recent preclinical study found functional improvement in rats with focal G-CSF. There are on going clinical studies with G-CSF in acute ischemic stroke.

Currently guidelines are being formulated to guide further research into the role of stem cell therapy in both translational and basic research areas. ${ }^{[45,46]}$

\section{Indian Scenario: Current Status}

Fortunately, some of the major public sector tertiary care centers and institutes are presently conducting peer reviewed scientific studies on various aspects of stem cell therapy in stroke patients as well as in animal models of stroke. Ongoing projects include, multicenter study on autologous bone marrow derived naïve mono nuclear cells infusion intravenously in patients with acute ischemic stroke, randomized within one month of acute event, sponsored by the Department of Biotechnology (DBT), Government of India; multicenter study on G-CSF in acute ischemic stroke; role of autologous bone marrow derived expanded stromal cells infusion intravenously in patients with chronic (>3 months-2 years) of acute ischemic stroke, sponsored by the Department of Science and Technology (DST) , Government of India. Results of these on going projects are eagerly awaited.

There are reports of unmonitored, outside experimental protocol "treatments" with various varieties of "stem cells" for a variety of "incurable" diseases being given by "self-proclaimed" stem cell specialists in India and elsewhere reporting "unparalleled" success stories in media. These reports have triggered an avalanche of patients and care givers of patients with degenerative disorders and as yet incurable diseases making a bee line to these unproven interventions. Currently there seems to be no law to curtail these unscientific activities.

\section{Conclusion}

Basic and clinical research in stroke, neurotransplantation remains in a nascent stage. Much more work is needed to further characterize the biology of different implant sources both in vitro and in vivo.

\section{References}

1. Johansson BB. Brain plasticity and stroke rehabilitation. Stroke 2000;31:223-30.

2. Okano H. Stem cell biology of the central nervous System. J. Neurosci Res 2002;69:698-707.

3. Stem cell basics: National Institute of Health. stem cells.nih.gov/ infocenter/stem cell basics.asp.

4. Zivin JA. Cell transplant therapy for stroke: Hope or hype. Neurology 2000;55:467. 
5. Savitz SI, Rosenbaum DM, Dinsmore JH, Wechsler LR, Caplan LR. Cell transplantation for stroke. Ann Neurol 2002;52:266-75.

6. Bjorklund A, Lindvall O. Cell replacement therapies for central neurons systems disorders. Nature Neuroscience 2000;3:537-44.

7. Issacson O, Deacon T. Neural transplantation studies reveal the brain capacity for continous reconstruction. Trends Neurosci 1997;20:477-82.

8. Brevig T, Holgersson J, Widner H. Xenotransplantation for CNS repair: Immunological barriers and strategies to overcome them. Trends Neurosci 2000;23:337-4

9. Boer GJ. Ethical issues in neurografting of human embryonic cells. Theor Med Bioeth 1999;20:461-75.

10. Cozzi E, White DJ. The generation of transgenic pigs as potential organ donors for humans. Nat Med 1995;1:964-66.

11. Jacoby DB, Lindberg C, Cunningham MG, Ratliff J, Dinsmore J. Long term survival of fetal porcine lateral ganglionic eminence cells in the hippocampus of rats. J Neurosci Res 1999;56:581-94.

12. Edge AS, Gosse ME, Dinsmore J. Xenogeneic cell therapy: Current progress and future development in porcine cell transplantation. Cell Transplant 1998;7:525-39.

13. Patience C, Takeuchi Y, Weiss RA. Infection of human cells by an endogenous retrovirus of pigs. Nat Med 1997;3:282-56.

14. Staines WA, Morassutti DJ, Reuhl KR, Ally AI, McBurney MW. Neurons derived from P19 embryonal carcinoma cells have varied morphologies and neurotransmitters. Neuroscience 1994;58:735-51.

15. Magnuson DS, Morassutti DJ, Staines WA, McBurney MW, Marshall KC. In vivo electrophysiological maturation of neurons derived from a multipotent precursor (embroymal carcinoma) cell line. Brain Res Dev Brain Res 1995;84:131-41.

16. Pleasure SJ, Lee VM. N Tera 2 cells: A human cell line which displays characteristics of a human committed neural progenitor cells. J Neurosci Res 1993;35:585-602.

17. Pleasure SJ, Page C, Lee VM. Pure, post mitotic polarized human neurons derived from $\mathrm{N}$ Tera 2 cells provide a system for expressing exogenous proteins in terminally differentiated neurons. J Neurosci 1992;12:1802-15.

18. Guillemain I, Alonso G, Patey G, Privat A, Chaudieu I. Human N'T2 neurons express a variety of neurotransmission phenotypes in vitro. J Comput Neurol 2000;422:385-95.

19. Hartley RS, Margulis M, Fishman PS, Lee VM, Tang CM. Functional synapses are found between human N Tera $2\left(\mathrm{NT}^{\prime} 2 \mathrm{~N}, \mathrm{hNT}\right)$ neurons grown on astrocytes. J Comp Neurol 1999;407:1-10.

20. Okano H. Neural stem cells; progression of basic research and prospective for clinical application. Keio J Med. 2002;51:115-128.

21. Svendsen CN, Caldwell MA. Neural stem cells in the developing nervous system: Implication for cell therapy through transplanatation. Prog Brain Res 2000; 127; 13-34.

22. Nakamura Y, Sakakibara S, Miyata T, Ogawa M, Shimazaki T, Weiss S, et al. The bHLH gene Hes1 as a repressor of neuronal commitment of the CNS stem cells. J Neurosci 2000;20:283-93.

23. Pencea V, Bingaman KD, Wiegand SJ, Luskin MB. Infusion of brain derived neurotrophic factors into the lateral ventricle of adult rat leads to new neurons in the parenchyma of the striatum, septum, thalamus, and hypothalamus. J Neurosci 2001;21:6706-17.

24. Sanchez-Ramos JR. Neural cells derived from adult bone marrow and umblical cord blood. J Neurosci Res 2002;69:880-93.

25. Sanchez-Ramos J, Song S, Cardozo-Pelaez F, Hazzi C, Stedeford T, Willing $\mathrm{A}$, et al. Adult bone marrow stromal cells differentiate into neural cells in vitro. Exp Neurol 2000;164:247-56.

26. Woodbury D, Schwarz E.J, Prockop DJ, Black IB. Adult rat and human bone marrow stromal cells differentiate into neurons. J Neurosci Res 2000;61:364-70.

27. Sanchez-Ramos JR, Song S, Kamath SG, Zigova T, Willing A, Cardozo-
Pelaez F, et al. Expression of neural markers in human umbilical cord blood. Exp Neurol 2001;171:102-15.

28. Koji A. Therapeutic potential of neurotrophic factor and neural stem cells against ischemic brain injury. J. Cereb Blood Flow Met 2000;20:1393-408

29. Nishino H, Borlongan CV. Restoration of function by neural transplantation in the ischemic brain. Prog Brain Res 2000;127:461-76.

30. Eriksson PS, Perfilieva E, Björk-Eriksson T, Alborn AM, Nordborg C, Peterson DA, et al. Neurogenesis in adult human hippocampus. Nat Med 1998;4:1313-7.

31. Hodges H, Sinden J, Meldrum B, Gray. In: Dunnett B, Bjorklund A, editors. Functional Neural Transplantation. New York: Raven; 1994. p. 347-86.

32. Hodges H, Sowinski P, Fleming P, Kershaw TR, Sinden JD, Meldrum BS, et al. Contrasting effects of fetal CA1 and CA3 hippocampal grafts on deficits in spatial learning and working memory induced by global cerebral ischaemia in rats. Neuroscience 1996;72:959-88.

33. Sorensen JC, Grabowski M, Zimmer J, Johansson BB. Fetal neocortical tissue blocks implanted in brain infarcts of adult rats interconnect with the host brain. Exp Neurol 1996;138:227-35.

34. Mattsson B, Sorensen JC, Zimmer J, Johansson BB. Neurol grafting to experimental neocortical infarcts improves behavioral outcome and reduces thalamic atrophy in rats housed in enriched but not in standard environments. Stroke 1997;28:1225-32.

35. Sotelo C, Alvarado - Mallart RM. The reconstruction of cerebellar circuits. Trends Neurosci 1991;14:350-5.

36. Chen J, Li Y, Wang L, Zhang Z, Lu D, Lu M, Chopp M. Therapeutic benefit of intravenous administration of bone marrow stromal cells after cerebral ischaemia in rats. Stroke 2001;32:1005-611.

37. Chen J, Sanberg PR, Li Y, Wang L, Lu M, Willing AE, et al. Intravenous administration of human umblical cord blood reduces behavioral deficits after stroke in rats. Stroke 2001;171:109-15.

38. Mudrick LA, Bainbridge KG. Hippocampal neurons transplanted into ischemically lesioned hippocampus: Anatomical assessment of survival, maturation and integration. Exp Brain Res 1991;86:233-47.

39. Aoki H, Onodera H, Yae T, Jian Z, Kogure K. Neural grafting to ischemic CA1 lesions in rat hippocampus: An autoradiographic study Neurosci 1993;56:345-54

40. Kondziolka D, Wechsler L, Achim C. Neural transplantation for stroke. J Clin Neuroscience 2002;9:225-30.

41. Kondziolka D, Wechsler L, Goldstein S, Meltzer C, Thulborn KR, Gebel J, et al. Transplantation of cultured human neuronal cells for patients with stroke. Neurology 2000;55:565-9.

42. Meltzer CC, Kondziolka D, Villemagne VL, Wechsler L, Goldstein S, Thulborn KR, et al. Serial (18F) flourodeoxyglucose position emission tomography after human neural implantation for stroke. Neurosurgery 2001;49:586-91.

43. Kondziolka D, Wechsler L, Tyler-Kabara E, Achim C. The role of cell therapy for stroke. Neurosurg Focus 2002;13:1-6.

44. Bang OY, Lee JS, Lee PH, Lee G. Autologous mesenchymal stem cell transplantation in stroke patients: Ann Neurol 2005;57:874-82.

45. Borlongan CV. Cell therapy for stroke: Remaining issues to address before embarking on clinical trials. Stroke 2009;40:S146-8.

46. The STEPS Participants. Stem Cell Therapies as an Emerging Paradigm in Stroke (STEPS). Bridging basic and clinical science for cellular and neurogenic factor therapy in treating stroke. Stroke 2009;40:510-5.

Accepted on 24-07-2009

Source of Support: Nil, Conflict of Interest: None declared. 